\title{
THE ACTIVITY OF PANCREATIC ENZYMES ON DIFFERENT STAGES OF METABOLISM IN BROILER CHICKS
}

\section{V.G. VERTIPRAKHOV, A.A. GROZINA, A.M. DOLGORUKOVA}

All-Russian Research and Technological Institute of Poultry, Federal Agency of Scientific Organizations, 10, ul. Ptitsegradskaya, Sergiev Posad, Moscow Province, 141300 Russia, e-mail Vertiprakhov63@mail.ru, alena_fisinina@mail.ru, anna.dolg@mail.ru

Received February 2, 2016

\section{Abstract}

The pancreas is one of the most important digestive organs releasing the enzymes which hydrolyze all main nutrients to monomers capable of absorption into blood and lymph. The production of hydrolytic enzymes within the cells of digestive glands is submitted to general principles of protein synthesis, and the mechanisms involved have been studied in detail (R.M. Case, 1998). It is not a case, however, for urgent transportation of these enzymes by specialized secretory cells (glandulocytes), a recretory process including the absorption of endogenous secrets from blood stream by glandulocytes with subsequent release of the immutable forms of these secrets within digestive juices. Exocrine secrets of digestive glands, therefore, contain two enzymatic pools: those synthesized de novo and recreted. Classic secretive physiology is focused on the first pool while second is often underestimated (G.F. Korot'ko, 2013). Analysis of enteropancreatic circulation of pancreatic enzymes (S.S. Rotman et al., 2002) supported the conclusion that under certain conditions only 25-50\% of total circulating pancreatic enzymes are synthesized de novo by the pancreas. Output of digestive enzymes into blood stream depends on the pancreas secretion. In this context the circulation of pancreatic enzymes in human and animals recently has drawn an attention, since these enzymes perform not only digestive but also regulatory function (R. Ramachandran et al., 2008; G.F. Korot'ko, 2011; R. Gru auskas et al., 2015). In the article the experimental data on the activities of pancreatic enzymes in pancreatic juice, duodenal chymus, blood serum, and feces in broiler chicks (Cobb 500, $n=6$ ) are presented. The chicks were operated to collect the pancreatic juice according to unique poultry fistulation method (Ts.Zh. Batoev and S.Ts. Batoeva, 1970) allowing the sampling of pancreatic juice during the trial and redirection of the juice into the intestine thereafter without any detrimental effect on health and welfare of poultry. Blood pancreatic enzyme activity and activity in litter were also assayed. The post-feeding secretive dynamics of pancreatic juice and enzymes is presented. The results of our physiological investigation showed that complex-reflex regulatory phase of pancreatic secretion continues during $120 \mathrm{~min}$ after feeding with the subsequent transition to neurohumoral phase (mediated by secretion of hormones secretin and cholecystokinine into the blood stream) when chymus reaches the intestine. Analysis of duodenal chymus showed for intestinal enzymatic activities a pattern similar to the dynamics in pancreatic juice although fluctuations in duodenal activities of amylase, lipase and proteases were less distinct. Our results recirculation into showed that the pancreatic enzyme pool in the body is mostly due to synthesis de novo. The pancreatic enzymes involved in intestinal digestion then mostly undergo the blood stream, only minor part of activated enzymes being excreted with feces. The enzymes enter the blood stream unevenly: for duodenum, the blood lipase activity is the least, blood amylase activity is intermediate and blood protease activity is high. The closest amylase/protease ratio in pancreatic juice and blood serum was determined; this parameter could be used in diagnostics of physiological condition of the pancreas in chicken.

Keywords: pancreatic enzymes, pancreatic juice, intestinal enzymatic activities, pancreatic enzymes in blood serum, broiler chicks

The pancreas is one of the most important digestive organs producing the enzymes, which hydrolyze all major nutrients into monomers that can be absorbed into the blood or lymph. The production of hydrolytic enzymes by the cells of digestive glands is subject to general principles of protein synthesis. The mechanisms involved have been studied in detail elsewhere [1]. Also, there exists an immediate transportation of these enzymes by specialized secretory cells (glandular cells), i.e. a process of reabsorption involving the absorption of en- 
dogenous secretory products from the blood stream by glandular cells and their subsequent excretion in the unchanged form as a part of digestive juices. Thus, external secretions of the exocrine digestive glands consist of two enzymatic pools, namely, those synthesized de novo and the reabsorbed ones. Classic physiology of the digestive secretion focuses on the first pool, while often neglecting the second one [2-4]. Based on the assessment of enteropancreatic circulation of pancreatic enzymes, S.S. Rothman et al. [5] concluded that, under certain conditions, the pancreas was incapable of producing more than $25-50 \%$ of total circulating pancreatic enzymes.

The entry of pancreatic enzymes into the bloodstream correlates with the mechanism of the pancreatic secretion regulation: first, this helps maintain the enzymatic homeostasis, and, second, it enables the reabsorption of enzymes from the blood as a substrate for the acinar functional unit of the pancreas [2]. In this regard, in recent years, there is a large increase in interest to the of pancreatic enzyme circulations in humans and animals, as the enzymes both participate in digestion and contribute to the regulatory functions in the body [6-9]. Moreover, investigation of pancreatic enzymes circulation in animals is essential for understanding the lack of enzymes during digestion and their use as biochemical markers for the assessment of the pancreas.

There are data on digestibility of amino acids in the fowl [10], morphometric [11] and cytological [12] patterns of the secretory unit of the exocrine pancreas, and enzyme activity in the pancreas tissues [3, 13, 14]. However, in these investigation the pancreatic enzymes were studied in vitro. There were only few digestion studies carried out abroad in chickens, based on an experimental model involving the chronic fistula technique $[15,16]$.

Here, for the first time, we compared the in vivo activity of pancreatic enzymes in pancreatic juice, duodenal chymus, blood and feces in the poultry of the modern crossing. Carrying on a tradition of the the Russian School in Physiology founded by I.P. Pavlov, the fistula method was used in the digestion evaluation that allowed assessing the organ regulation without disturbing the natural physiological and biochemical processes, and identifying the effects of various factors (additives, feed, etc.) at the whole body level. We suppose this approach is of the greatest scientific and practical importance.

The study objective was to determine the activity of pancreatic enzymes in different biological matrices in fistulized broiler chickens.

Technique. Investigations were carried out on meat chickens of the Cobb 500 cross in the vivarium (All-Russian Research and Technological Institute of Poultry, VNITIP). The feeding and breeding of the studied broilers complied with the VNITIP's guidelines. Physiological experiments were performed in two groups (3 chickens in each group).

In one group, chickens aged over 20 days were operated to obtain the duodenal chymus. The fistula was implanted into the duodenum at the site opposite to the confluence of the pancreatic and bile ducts. Investigations were initiated in 3-5 days, when the chickens recovered. Chickens were fixed in a special machining device. The first portion of chymus was collected in fasted chickens, then the chickens were fed with $30 \mathrm{~g}$ of feed, and the next chymus samples were collected 1 and 2 hours after feeding. Each chymus sample ( 3 to $5 \mathrm{ml}$ ) was centrifuged, diluted with Ringer's solution (1:50) and used to determine enzyme activity.

In another group, the exocrine function of the pancreas was investigated in broiler chickens (aged $\geq 30$ days) having a chronic fistula implanted in the pancreatic duct using the method proposed by Ts.Zh. Batoev and S.Ts. Batoeva [17]. The physiological experiment lasted for 180 minutes. In the first 30 minutes, the amount of pancreatic fluids was determined along with its enzyme 
activity in fasted animals who further received $30 \mathrm{~g}$ of food. Next, pancreatic juice was collected every 30 minutes, with the amount measured and enzymatic activity evaluated.

The amylase activity was determined by modified Smith and Roy's method [18], protease activity was measured colorimetrically based on casein hydrolysis [19], and for lipase activity a biochemical analyzer Chem well 2900 (T) (Awareness Technology, Inc., USA) and Human (HYMAH, Germany) reagent kit were used.

After the physiological experiments were completed, blood was sampled from the axillary vein, heparinized, and centrifuged for 5 minutes at 5,000 rpm to assess the activity of pancreatic enzymes in the blood plasma.

The enzyme activity in the feces from chickens after the end of the physiological experiment was evaluated using the same methods.

At least 10 tests were performed in each chicken.

Statistical analysis was performed by conventional methods using Student's $t$-test.

Results. The findings demonstrated that the pancreas produces the largest amount of enzymes involved in the intestinal digestion (Table).

The activity of pancreatic enzymes involved in the digestion in broiler chickens of the

Cobb 500 cross ( $M \pm m$, physiological experiment)

\begin{tabular}{|c|c|c|c|c|c|}
\hline Parameter & A & B & $\mathrm{C}$ & D & A:B:C:D \\
\hline Amylase, $\mathrm{mg} /(\mathrm{ml} \cdot \mathrm{min})$ & $4,677 \pm 832.3$ & $1,073 \pm 229.2$ & $8 \pm 0.7$ & $16 \pm 6.8$ & $585: 134: 1: 2$ \\
\hline Lipase, U/1 & $3,200 \pm 201.9$ & $3,950 \pm 359.7$ & $12 \pm 3.9$ & $50 \pm 12.5$ & $267: 329: 1: 4$ \\
\hline Proteases, $\mathrm{mg} /(\mathrm{ml} \cdot \mathrm{min})$ & $215 \pm 37.9$ & $40 \pm 7.3$ & $0.4 \pm 0.10$ & $4 \pm 0.6$ & 537:100:1:10 \\
\hline Amylase/proteases & $22: 1$ & $27: 1$ & $20: 1$ & $4: 1$ & \\
\hline
\end{tabular}

A relatively small amount of active pancreatic enzymes was excreted from the body with feces. In the feces the enzyme activity was 67 times lower for amylase, 79 times lower for lipase and 10 times lower for proteases as compared to that in the duodenum. These data confirm the reabsorption of enzymes, one of the ways of which is a return of the pancreatic enzymes through the intestine into the blood. The process is similar to the kidney reabsorption, when nutrients and minerals necessary for the body return once again from the primary urine into the blood. However, pancreatic enzymes entered the blood unevenly: when compared to the activity in the duodenal chymus, the lowest activity in the blood was seen for lypase, moderate for amylase, and relatively high for proteases. It appeared to be due to the intrinsic structure of enzyme molecules [20-22]. The lowest amylase to protease ratio in the feces was indicative of a relatively higher excretion of proteases with feces (see Table).

When discussing the findings, it should be kept in mind that the used method of implanting the pancreatic duct fistula is unequalled in the world practice, it allows obtaining pancreatic juice only within the frame of the physiological experiments, and in the rest of the time directing it through an external anastomosis in the intestine, thereby minimizing the adverse effects of fistulation; also, it gives the opportunity to investigate the exocrine pancreatic function on a healthy fowl for a long time.

S.S. Rothman et al. [5] reported that 50-65\% or more of labeled and unlabeled amylase and chymotripsin are extensively absorbed from the human small intestine. H.C. Heinrich et. al [23] reported about 50-70\% absorption of trypsin. A.A. Aliev [24] demonstrated that lipase, amylase and maltase were absorbed from the small intestine into the lymph flowing out of it.

Regarding the pancreatic enzymes in the blood, amylase and lipase were 
in their primary form, while proteases were bound to trypsin inhibitors and did not exhibit enzymatic activity [2, 20-22]. The amylase to protease ratios in the pancreatic juice and blood were similar, which can be used for diagnostics of the pancreatic state.

Significant differences were observed in the enzyme activity in the pancreatic juice and the duodenal chymus. When the pancreatic juice was released into the intestine, amylase and protease activities decreased by about 5 times (see Table). However, lipase activity in the intestine was at the same level as in pancreatic secretion $(\mathrm{p} \geq 0.05)$. This can be explained by the promoting activity of bile, which was released in the intestine simultaneously with pancreatic juice.

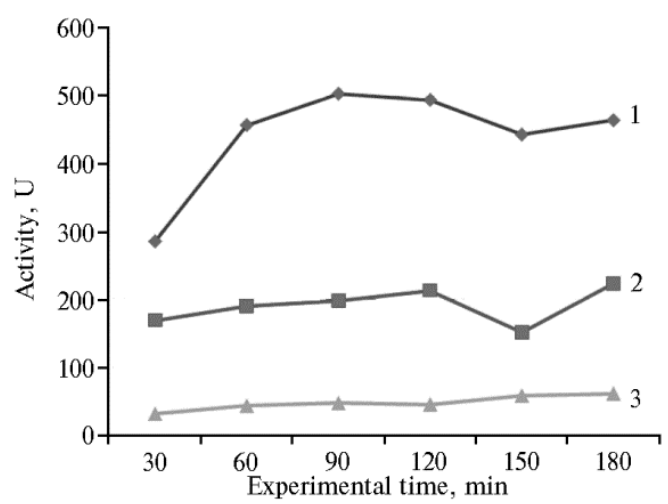

Fig. 1. The enzyme activity in pancreatic juice of Cobb 500500 cross chickens after food intake: 1 - amylase, $\times 10 \mathrm{mg} /(\mathrm{ml} \cdot \mathrm{min}) ; 2$ - proteases, $\mathrm{mg} /(\mathrm{ml} \cdot \min ) ; 3-$ lipase, $\times 50 \mathrm{U} / 1$ (physiological experiment).

The amylase-protease ratio increased in the intestinal chymus as compared to that in the pancreatic juice, which could be due to the presence of additional amylolytic enzymes from saliva and digestive juices.

In 1 hour after food administration, the amylase activity in the pancreatic juice increased almost 2fold and maintained until the end of the experiment (Fig. 1). The proteases activity reached its maximum, increasing by 1.3 times, at $1.5 \mathrm{~h}$ after food administration, subsequently it somewhat reduced and raised again to a maximum within the period corresponding to the phase of the neurochemical regulation of pancreatic secretion. The lipase activity increased gradually, reaching its peak level at the end of the experiment, when it was 2.0 times higher than at baseline (before feeding).

Following the feed intake, enzyme activity curves sharply rushed upwards (see Fig. 1). The reaction is initiated within the cephalic phase of pancreatic secretion. In this, the exocrine gland function is influenced both by signals and unconditioned reflexes [25-28]. The reflex arc starts with oral receptors, and then

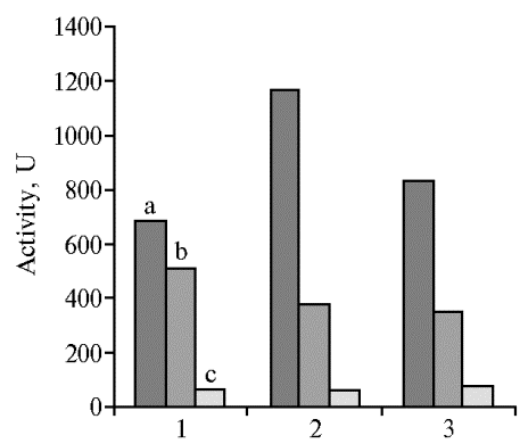

Fig. 2. The enzyme activity in duodenal chymus of Cobb 500 cross chickens before (1), 1 hour after (2) and 2 hours (3) after feeding: a - amylase, $\mathrm{mg} /(\mathrm{ml} \cdot \mathrm{min}) ; \quad \mathrm{b}-$ proteases, $\times 0.1$ $\mathrm{mg} /(\mathrm{ml} \cdot \mathrm{min}) ; \mathrm{c}-$ lipase, $\times 50 \mathrm{U} / 1$ (physiological experiment). signals are transmitted to the digestion center in medulla oblongata, from where the impulses are transmitted downwards to the pancreas along parasympathetic nerves [29]. Therefore, the initial reaction can be used in characterization of the feed taste. After a 120-minute cephalic phase the neurochemical regulation of the pancreatic secretory function is triggered. Its mechanisms are associated with entering gastric contents into the intestine and a release of secretin (it influences the amount of juice) and pancreozymin/cholecystokinin (it substantially affects the amount of enzymes) $[26,29]$. The peak is associated with the feed nutritional value. The variations in the activity of pancreatic enzymes were also established in hens after feeding [28].

Fluctuations in the enzymatic activity of the chymus and the pancreatic 
secretion were slightly different (see Fig. 2). The most extensive (by 1.7 times) rise after feed intake was seen for the amylolytic activity. The lipase activity increased (from $3,450 \pm 370.2$ to $4,050 \pm 420.5 \mathrm{U} / \mathrm{l}$ ) 2 hours after feed intake. The proteolytic activity of the chymus did not change significantly at the end of the experiment, increasing from $51 \pm 17.9$ to $35 \pm 10.2 \mathrm{mg} /(\mathrm{ml} \cdot \mathrm{min})$.

Thus, in broilers, enzymes from the pancreas are first directed to the duodenum where they contribute to the hydrolysis of the feed nutrients, and then absorbed in the blood. A minor part of the active enzymes is eliminated from the body in feces. Feeding is a powerful stimulus of pancreatic secretion. The cephalic phase of the pancreatic regulation in broilers lasts for 120 minutes starting immediately after the feed intake. The variations in the enzyme activity in the intestine after feed intake are similar to those in the pancreatic juice, although fluctuations in the duodenal activity of amylase, lipase and proteases are not so pronounced. The closest amylase-protease enzyme ratios are observed in pancreatic juice and blood, which can be used for diagnostics of pancreatic function.

\section{REFEREN C ES}

1. Cas e R.M. Pancreatic exocrine secretion: mechanisms and control. In: The pancreas. H.G. Beger et al. (eds.). Blackwell Science, Berlin, 1998. V. 1: 63-100.

2. Kor ot'k o G.F. Fizicheskaya kul'tura, sport - nauka i praktika, 2013, 1: $51-57$ (in Russ.).

3. Krogdahl A., S e 11 J.L. Influence of age on lipase, amylase, and protease activities in pancreatic tissue and intestinal contents of young turkeys. Poultry Sci., 1989, 68(11): 1561-1568 (doi: 10.3382/ps.0681561).

4. Ro m e ro L.F., Plu mste a d P.W. Bio-efficacy of feed proteases in poultry and their interaction with other feed enzymes. Zootechnica international, 2014, 36: 48-60.

5. Rothman S.S., Li e bow C., I s e $\mathrm{nm}$ a n L. Conservation of digestive enzymes. Physiol. Rev., 2002, 82: 1-18 (doi: 10.1152/physrev.00022.2001).

6. R a m a chand ran R., Holle $\mathrm{nberg}$ M.D. Proteinases and signalling: pathophysiological and therapeutic implications via PARs and more. Br. J. Pharmacol., 2008, 153: 263-282 (doi: 10.1038/sj.bjp.0707507).

7. Kawabata A., Matsunami M., Sekiguchi F. Gastrointestinal roles for proteinaseactivated receptors in health and disease. Review. Br. J. Pharmacol., 2008, 153: 230-240 (doi: 10.1038/sj.bjp.0707491).

8. Korot'k o G.F. Retsirkulyatsiya fermentov pishchevaritel'nykh zhelez [Recycling enzymes of digestive glands]. Krasnodar, 2011 (in Russ.).

9. Gruzhauskas R., Ratsivichyute-Stupeliene A., Slausgalvis V., Shas hite V., Klishevichyute V., Al-Saifi D., Shtefan B., Kurkletis A. Materialy XVIII Mezhdunarodnoi konferentsii "Innovatsionnoe obespechenie yaichnogo $i$ myasnogo ptitsevodstva Rossii» [Proc. XVIII Int. Conf. «Innovative aspects of egg and meat poultry in Russia]. Sergiev Posad, 2015: 453-455 (in Russ.).

10. Y a p o n t s e A.E. Ptitsevodstvo, 2016, 2: 35-37 (in Russ.).

11. S o m o v a O.V. Uchenye zapiski UO VGAVM, 2012, 48(1): 142-145 (in Russ.).

12. S o m o v a O.V., G u d k o v F.D. Uchenye zapiski UO VGAVM, 2010, 46(1): 50-53 (in Russ.).

13. Einzhel R. Zootecnica Mezhdunarodnyi ptitsevodcheskii zhurnal, 2013, 9(59): 32-44 (in Russ.).

14. Murai A., Satoh S., Okumura J., Furuse M. Factors regulating amylase secretion from chicken pancreatic acini in vitro. Life Sci., 2000, 66(7): 585-591 (doi: 10.1016/S00243205(99)00631-1).

15. Degolie r T.F., Pla c e A.R., D uke G.E., C a rraw ay R.E. Neurotensin modulates the composition of pancreatic exocrine secretions in chickens. J. Exp. Zool., 1999, 283: 455-462.

16. R e n L.Q., Zh a o F., Tan H.Z., Z h a o J.T., Z hang J.Z., Z hang H.F. Effects of dietary protein source on the digestive enzyme activities and electrolyte composition in the small intestinal fluid of chickens. Poultry Sci., 2012, 91(7): 1641-1646 (doi: 10.3382/ps.2011-02081).

17. B at o ev Ts.Zh., B a to v a S.Ts. Fiziol. zhurn. SSSR, 1970, 56(12): 1867-1868 (in Russ.).

18. M e ri n a - G 1 u z k i n a V.M. Laboratornoe delo, 1965, 3: 142-146 (in Russ.).

19. B a t o e v Ts.Zh. Sbornik nauchnykh trudov Buryatskogo SKHI (Ulan-Ude), 1971, 25: 122-126 (in Russ.).

20. Ri chardson J., Vis w a n a than K., Luc as A. Serpins, the vasculature, and viral therapeutics. Front. Biosci., 2006, 11(1): 1042-1056 (doi: 10.2741/1862).

21. Suzuki K. The multi-functional serpin, protein $\mathrm{C}$ inhibitor: beyond thrombosis and hemostasis. J. Thromb. Haemost., 2008, 6(12): 2017-2026 (doi: 10.1111/j.1538-7836.2008.03181.x). 
22. Z a vas nik-B e rga n t T. Cystatin protease inhibitors and immune functions. Front. Biosci., 2008, 1(13): 4625-4637 (doi: 10.2741/3028).

23. H e i n ri c h H.C., G a b b e E.E., B r ügge ma n n J., I c a gi c F., C las s e n M. Enteropancreatic circulation of tripsin in man. Klin. Wochensch., 1979, 57: 1295-1297 (doi: 10.1007/BF01492985).

24. Ali e v A.A. Limfa i limfoobrashchenie u produktivnykh zhivotnykh [Lymph and lymph circulation in productive animals]. Leningrad, 1982 (in Russ.).

25. U g o l e v A.M. Evolyutsiya pishchevareniya i printsipy evolyutsii funktsii [Evolution of the digestion function and principles of functional evolution]. Leningrad, 1985 (in Russ.).

26. Kli mov P.K., Fo k in a A.A. Fiziologiya podzheludochnoi zhelezy. Regulyatsiya vneshnesekretornoi funktsii [The physiology of the pancreas. The regulation of exocrine function]. Leningrad, 1987 (in Russ.).

27. Vertiprakhov V.G. Pancreatic exocrine function in hens with addition of lysine and methionine to their ration. Russian Agricultural Sciences, 2015, 41(2-3): 171-174 (doi: 10.3103/S1068367415020275).

28. Verti p r a k hov V.G. Fiziologicheskie osnovy ispol'zovaniya belkovykh balansiruyushchikh dobavok $v$ ratsione zhivotnykh [Physiological basis for balancing animal diet with dietary proteins]. Chita, 2012 (in Russ.).

29. B at o e v Ts.Zh. Fiziologiya pishchevareniya ptits [Physiology of digestion in birds]. Ulan-Ude, 2001 (in Russ.). 